\title{
Soroprevalence of bovine alphaherpesvirus type 1 (BoHV-1) and risk factors associated with dairy properties of the municipality of Senador Guiomard, Acre, Brazil
}

\author{
Soroprevalência de alfaherpesvírus bovino tipo 1 (BoHV-1) e fatores de risco \\ associados em propriedades leiteiras do município de Senador Guiomard, Acre, Brasil \\ Eder Ferreira de Arruda1* (D), Tamyres Izarelly Barbosa da Silva² (D), Breno Bezerra Aragão3 (D), \\ Roberto Soares de Castro 3 (D), Yuri Almeida Gomes ${ }^{2}$ (iD)
}

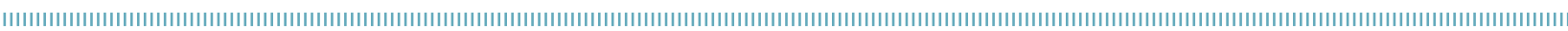

\begin{abstract}
Bovine alphaherpesvirus type 1 (BoHV-1) is the etiological agent responsible for serious infections that compromise the respiratory and genital tracts of affected cattle. In order to estimate the seroprevalence of BoHV-1 and to identify the associated risk factors in dairy farms in the city of Senador Guiomard, Acre, Brazil, the present study was carried out through the analysis of 180 blood serum samples submitted to the screening of anti-BoHV-1 by the virus neutralization test (VN) and by means of the evaluation of the epidemiological questionnaire applied in the eight investigated properties. The prevalence of seropositivity for BoHV-1 was $61.1 \%$, ranging from 43.3 to $86.2 \%$ among the analyzed properties. The variable absence of veterinary assistance showed statistically significant association (odds ratio $-\mathrm{OR}=2.10 ; \mathrm{p}<0.001$ ) with alphaherpesvirus infection. The results demonstrate that the frequency of BoHV-1 is high and needs to be controlled through prophylactic and health management measures.
\end{abstract}

KEYWORDS: livestock; epidemiological survey; virus neutralization.
RESUMO: O alfaherpesvírus bovino tipo 1 (BoHV-1) é o agente etiológico responsável por graves infecçôes que comprometem os tratos respiratório e genital dos bovinos acometidos. Com o objetivo de estimar a soroprevalência de BoHV-1 e identificar os fatores de risco associados em propriedades leiteiras do município de Senador Guiomard, Acre, foi realizado o presente estudo, por meio da análise de 180 amostras de soro sanguíneo submetidas à pesquisa de anticorpos anti-BoHV-1 pelo teste de vírus neutralização $(\mathrm{VN})$ e por meio da avaliação do questionário epidemiológico aplicado nas oito propriedades investigadas. A prevalência de soropositividade para BoHV-1 foi de $61,1 \%$ variando de 43,3 a $86,2 \%$ entre as propriedades analisadas. A variável ausência de assistência veterinária apresentou associação estatisticamente significativa (odds ratio $-\mathrm{OR}=2,10 ; \mathrm{p}<0,001)$ com a infecção pelo alfaherpesvírus. Os resultados demonstram que a frequência de BoHV-1 é alta e precisa ser controlada através de medidas profiláticas e de manejo sanitário.

PALAVRAS-CHAVE: pecuária; inquérito epidemiológico; vírus neutralização. 


\section{INTRODUCTION}

The bovine alphaherpesvirus type 1 (BoHV-1) belonging to the order Herpesvirales, family Herpesviridae, subfamily Alphaherpesvirinae and genus Varicellovirus is the etiological agent responsible for serious infections that compromise the respiratory and genital tracts of the affected animals. BoHV-1 can manifest clinically as bovine infectious rhinotracheitis (BIR) or infectious pustular vulvovaginitis / balanoposthitis (IPV / IPB), and infects mainly dairy and cutting cattle, but may also affect other domestic and wild species of ruminants (WORLD ORGANIZATION FORANIMAL HEALTH, 2010).

In the present study, BoHV-1 infection caused significant economic losses in livestock, as it is one of the main agents causing embryonic and fetal death, abortion, reduced fertility, decreased milk production and difficulty in gaining weight (VIU et al., 2014).

In Brazil, serological and etiological evidence indicates that BoHV-1 is widely distributed in dairy herds and has been isolated and identified in all regions of the country. However, the frequency of infected animals is indeterminate and varies considerably depending on the locality analyzed. Studies have identified the prevalence of $51.9 \%$ in Goiás (BARBOSA et al., 2005), 54.6\% in Minas Gerais and São Paulo (ALEXANDRINO et al., 2011), $52.9 \%$ in Rio Grande do Sul (PIOVESAN et al., 2013), $14.0 \%$ in Amazonas (AGUIAR, 2014), 66.75\% in Espírito Santo (SANTOS et al., 2014), 63.23\% in Maranháo (FREITAS et al., 2014), and $57.54 \%$ in Santa Catarina (PASQUALOTTO et al., 2015).

In Acre state, the first report on the frequency of BoHV-1 was conducted by CAVALCANTE (1997), who examined 38 cattle from the experimental field of the Empresa Brasileira de Pesquisa Agropecuária (EMBRAPA) in Rio Branco and found prevalence of $44.73 \%$ positive animals. Another study, carried out by DINIZ et al. (2015) with 235 mestizo bovine females from 11 rural properties in six counties of Acre, confirmed the presence of anti-BoHV-1 antibodies in $43.82 \%$ of the evaluated females.

Despite the notorious health and economic importance of BoHV-1 infection, there is still a limitation of studies investigating its frequency and associated risk factors in Amazon cattle herds, especially in Acre, mainly due to the difficulties of access and the scarcity of human resources, material technology, finances and diagnostics.

Given the above, the present study aimed to estimate the BoHV-1 seroprevalence and to identify possible associated risk factors in dairy farms in the municipality of Senador Guiomard, Acre, Brazil.

\section{MATERIALS AND METHODS}

The present work deals with a cross-sectional study carried out in the rural area of Senador Guiomard (10009'08" S; $\left.67^{\circ} 44^{\prime 2} 21^{\prime \prime} \mathrm{W}\right)$. This municipality belongs to the dairy basin of the Rio Branco Microregion. The total bovine herd of Senador Guiomard identified in the 2010 by Demographic Census was 213,369 animals, of which 7,996 were identified with milk aptitude (IBGE, 2010).

For the calculation of the sample, the size of the dairy herd of the study area, the estimated prevalence of $50 \%$, based on the results obtained in studies carried out in the state (CAVALCANTE, 1997; DINIZ et al., 2015), the confidence interval of $95 \%$ (CI95\%) and the margin of error of $5 \%$, which determined a minimum sampling of 180 animals, were considered.

Between June and November 2016, 180 serological samples of non-vaccinated animals for the BoHV-1 were randomly collected, being 176 of female bovine and four males, with ages ranging from 2 to 8 years old. All were apparently healthy. These animals came from eight properties, distributed in the municipality that constitutes the study area, which were selected for non-probabilistic convenience.

Blood was collected through jugular venipuncture with a sterile disposable needle and vacuum tubes, previously identified with the animal number. After collection, the samples were centrifuged at 5,000 G for $10 \mathrm{~min}$ to obtain the serum. The serum aliquots were then stored in plastic microtubes and kept at $-20^{\circ} \mathrm{C}$ until the serological test (BEZERRA et al., 2012a).

For each of the eight properties, an epidemiological questionnaire composed of objective questions was used to obtain information about the type of exploration and management practices used to characterize the risk factors associated with BoHV-1 infection.

The analysis of the samples was carried out through the neutralization virus test (NV) at the Laboratório de Virologia Animal of the Universidade Federal Rural de Pernambuco, using the standards and procedures defined by the World Organization for Animal Health (2010).

For the test, Madin-Darby bovine kidney (MDBK) and type culture collection (CCL-22) cells were used. The cells were cultured in Dulbecco's Modified Eagle Medium (DMEM), with penicillin ( $40 \mathrm{mg} / \mathrm{L}$ ) and streptomycin $(200 \mathrm{mg} / \mathrm{L})$ supplemented with $4 \%$ fetal bovine serum $\left(\right.$ Sigma $\left.{ }^{\circledR}\right)$ (SANTOS et al., 2014).

In the test, 96 polystyrene plates were used, with constant dilution of the serum (1:2), versus 100 infective doses to $50 \%$ of the cell cultures / well (Infecting Dose for 50\% of Cell Cultures - DICC50) for the BoHV-1 isolate. Antibody detection was performed by incubating dilutions in the base $2(1: 2$ and 14$)$ of the serum against constant virus doses in duplicate.

After incubation of the virus serum for 24 hours at $37^{\circ} \mathrm{C}$ and $5 \% \mathrm{CO}_{2}$, a suspension of MDBK cells was added $(400,000 / \mathrm{mL})$, followed by incubation in $\mathrm{CO}_{2}$ oven at $37^{\circ} \mathrm{C}$. The reading was performed after 72 hours of incubation, through cytopathic effect (CPE) research. It was considered a 
positive sample when in the absence of $\mathrm{CPE}$, indicating viral neutralization, and negative in the presence of CPE (SILVA et al., 2015).

In the statistical analysis, the frequency measures of BoHV-1 infection were calculated, and the strength of the association between the risk factors (independent variables) and the diagnostic test result (dependent variable) was evaluated through odds ratio (OR), with their respective CI95\%.

For this, Fisher's exact test was used, and $\mathrm{p}$ value less than 0.05 was considered statistically significant, according to the program Statistical Package for the Social Sciences (SPSS, IBM, New York, United States), in the version 21.0.

The study was approved by the Committee on Ethics in Animal of the Universidade Federal do Acre, as determined by process No. 23107.010820/2015-10 and protocol No. $64 / 2015$, being in accordance with the ethical principles in animal experimentation established by the National Council of the Control of Animal Experimentation and Federal Council of Veterinary Medicine.

\section{RESULTS AND DISCUSSION}

The overall prevalence of seropositive animals for BoHV-1 was $61.1 \%$ (Table 1). This result resembles the values found by DIAS et al. (2008) in Paraná (64.41\%) and by SOUSA et al. (2013) in Maranhão (67.3\%). However, it differs from the prevalence obtained by HOLZ et al. (2009) in Rio Grande do Sul (29.2\%), AGUIAR (2014) in Amazonas (14.0\%) and OLIVEIRA et al. (2015) in Paraná (14.25\%) - they were lower frequencies. On the other hand, it is also distinguished from the seroprevalences recorded by OKUDA et al. (2006) in Rondônia (86.2\%), GUARINO et al. (2008) in Uruguay (99\%) and AFFONSO et al. (2010) in Goiás (84.5\%), for having verified higher values of seropositivity for BoHV-1.

The variation in the prevalence of BoHV-1 found in these studies can be explained by the type of breeding, management of animals, age range of animals, sampling techniques, diagnostic methods, and regional characteristics of each study.

The prevalence of BoHV-1 infection in the dairy herd of the municipality of Senador Guiomard is considered high, which shows that the virus is present and widely disseminated in the region. However, this value may be even higher, since the seropositivity found does not accurately reflect the number of infected animals and previous studies have demonstrated the existence of latently infected animals seronegative to the diagnostic tests.

According to TAKIUCHI et al. (2001), among the main reasons for the high frequency of infected animals in a given area are the lack of knowledge about the existence and transmission of the virus, its probable respiratory and reproductive consequences, as well as the main forms of prophylaxis and viral control. Already for DEL FAVA et al. (2002), the high prevalence rates of BoHV-1 can be justified by age, sex, type of breeding, management and exploration of the animals that constitute the risk factors for infection.

Regarding sex, $61.4 \%$ of the females and $50.0 \%$ of the males were seroreactive in the population evaluated (Table 1). Because they came from dairy herds, most of the positive animals was expected to be female, similar to the study by SILVA et al. (2015), in which the majority of BoHV-1 seropositive animals was found to be female. As for the breeders, half of the analyzed ones also presented seropositivity to the alphaherpesvirus, which demonstrates and emphasizes the relevance of the male in the spread of the infection. According to OLIVEIRA et al. (2011), infected bulls can transmit BoHV-1 directly by natural or indirect mating through contaminated semen during artificial insemination, thus contributing to the increase of low rates of return to service, shortening of the estrous cycle and low rate of fertilization in the infected females and favoring the maintenance of the virus in the establishment.

All of the eight investigated properties presented positive animals, and the prevalence distribution by property ranged from 43.3 to $86.2 \%$ (Table 1). Similar results were verified by BEZERRA et al. (2012a, 2012b) in Maranhão; both studies similarly found seropositive animals for BoHV-1 in all analyzed properties. According to ACKERMANN; ENGELS (2006), once the animal is infected by the alphaherpesvirus,

Table 1. Prevalence of bovine alphaherpesvirus type 1 infection by sex, age group and dairy properties in the municipality of Senador Guiomard, Acre, Brazil.

\begin{tabular}{lcccc} 
& \multicolumn{4}{c}{ Viral neutralization } \\
\cline { 2 - 5 } Variable & \multicolumn{2}{c}{ Positive } & \multicolumn{2}{c}{ Negative } \\
\cline { 2 - 5 } & $\mathbf{n}$ & $\%$ & $\mathbf{n}$ & $\%$ \\
\hline Sex & & & & \\
\hline Female & 108 & 61.4 & 68 & 38.6 \\
\hline Male & 2 & 50.0 & 2 & 50.0 \\
\hline Age Group & & & & \\
\hline 2 to 4 years old & 38 & 60.31 & 25 & 39.69 \\
\hline$>4$ years old & 72 & 61.53 & 45 & 38.47 \\
\hline Properties & & & & \\
\hline 1 & 11 & 73.4 & 4 & 26.6 \\
\hline 2 & 8 & 80.0 & 2 & 20.0 \\
\hline 3 & 17 & 63.0 & 10 & 37.0 \\
\hline 4 & 11 & 47.8 & 12 & 52.2 \\
\hline 5 & 13 & 43.3 & 17 & 56.7 \\
\hline 6 & 25 & 86.2 & 4 & 13.8 \\
\hline 7 & 13 & 44.8 & 16 & 55.2 \\
\hline 8 & 12 & 70.5 & 5 & 29.5 \\
\hline Total & 110 & 61.1 & 70 & 38.9 \\
\hline & & & & \\
\hline
\end{tabular}


it becomes a carrier and source of infection, which endangers the health of other susceptible animals.

Regarding the risk factors, the statistical analysis revealed significant association $(\mathrm{p}<0.001)$ between the rate of infection by BoHV-1 and the absence of veterinary care, and the lack of veterinary medical services identified in this study was a risk factor to seropositivity to alphaherpesviruses (OR $=2.10$ ), as shown in Table 2 .

The finding of this study corroborates that one obtained by BEZERRA et al. (2012a), that when investigating dairy cattle in the Amazon region of Maranhão the presence of veterinary assistance as a protection factor was identified $(\mathrm{OR}=0.37)$ for the occurrence of viral infection, with significant statistical association ( $p<0.05$ ). Similarly, SOUSA et al. (2013) also verified the absence of veterinary assistance as a risk factor $(\mathrm{OR}=7,714)$ for increased exposure to the agent ( $\mathrm{p}<0.05)$. For BEZERRA et al. (2012b), the lack of veterinary medical assistance can contribute to the delay of diagnosis and the absence of implantation of programs of prophylaxis and infection control.
Regarding the age group, $61.53 \%$ of seropositivity was detected in animals aged four years old or more. ALEXANDRINO et al. (2011) report that the older the animals are, the more likely they are to contract BoHV-1, due to the longer exposure to the virus and the risk factors for infection. In addition, intensive management in older animals can lead to stress and intensify the reactivation of the latent virus in the environment, ensuring that the infection remains in the herd which favors viral dissemination to the rest of the flock.

However, in the present study, the age group did not present significant association, according to Table 2, differing from the results obtained by MAGAÑA-URBINA et al. (2005), in Mexico, where cows aged 4 years old or more had increased risk of BoHV-1 when compared to the younger ones (OR = 2.36), and by CARBONERO et al. (2011), in Ecuador, where the cows older than 4 years old were identified as a risk factor associated with infection $(\mathrm{OR}=1.44)$.

However, in this study, animals younger than two years old were not analyzed, which may explain the lack of statistical

Table 2. Risk factors associated with bovine alphaherpesvirus type 1 infection in dairy farms in the municipality of Senador Guiomard, Acre, Brazil.

\begin{tabular}{|c|c|c|c|c|}
\hline Variable & $\mathbf{n}$ & Positive VNT (\%) & OR $(95 \% \mathrm{Cl})$ & p-value \\
\hline \multicolumn{5}{|l|}{ Age Group } \\
\hline 2 to 4 years old & 63 & $38(60.31)$ & \multirow{2}{*}{$1.05(0.56-1.97)$} & \multirow{2}{*}{0.847} \\
\hline$>4$ years old & 117 & $72(61.53)$ & & \\
\hline \multicolumn{5}{|l|}{ Replenishment of animals } \\
\hline To recreate & 25 & $19(76.0)$ & \multirow{2}{*}{$1.11(0.83-1.34)$} & \multirow{2}{*}{0.123} \\
\hline Purchase & 155 & $91(58.70)$ & & \\
\hline \multicolumn{5}{|l|}{ Type of creation } \\
\hline Semiconfining & 46 & $25(54.34)$ & \multirow{2}{*}{$1.45(0.73-3.19)$} & \multirow{2}{*}{0.297} \\
\hline Extensive & 134 & $85(63.43)$ & & \\
\hline \multicolumn{5}{|l|}{ Sharing the grass } \\
\hline No & 51 & $37(75.54)$ & \multirow{2}{*}{$1.49(0.80-1.93)$} & \multirow{2}{*}{0.062} \\
\hline Yes & 129 & $73(56.58)$ & & \\
\hline \multicolumn{5}{|l|}{ Conditions of the Facilities } \\
\hline Suitable & 17 & $12(70.58)$ & \multirow{2}{*}{$1.62(0.92-1.80)$} & \multirow{2}{*}{0.709} \\
\hline Inadequate & 163 & $98(60.12)$ & & \\
\hline \multicolumn{5}{|l|}{ Veterinary assistance } \\
\hline Yes & 138 & $79(57.24)$ & \multirow{2}{*}{$2.10(1.18-2.99)$} & \multirow{2}{*}{$<0.001^{*}$} \\
\hline No & 42 & $31(73.80)$ & & \\
\hline \multicolumn{5}{|l|}{ Reproductive management } \\
\hline Natural mount & 163 & $98(60.12)$ & \multirow{2}{*}{$1.59(0.53-4.73)$} & \multirow{2}{*}{0.501} \\
\hline Reproductive biotechnology & 17 & $12(70.58)$ & & \\
\hline \multicolumn{5}{|l|}{ History of abortion } \\
\hline No & 36 & $27(75.24)$ & \multirow{2}{*}{$1.45(0.94-1.66)$} & \multirow{2}{*}{0.059} \\
\hline Yes & 144 & $83(57.63)$ & & \\
\hline
\end{tabular}

VNT: virus neutralization test; OR: odds ratio; $95 \% \mathrm{Cl}$ : confidence interval of $95 \%$. 
significance, since younger animals have less contact with adult animals, thus are less exposed to alphaherpesvirus.

The variables type of breeding and reproductive management also had no significant association (Table 2), but may be contributing to the infection, even to a lesser extent, since they presented representative OR and were already identified by SILVA et al. (2015) as potential risk factors in cattle herds in the state of Pernambuco, but without statistical significance.

As for the form of animal replacement, BARBOSA et al. (2005) report that the purchase of cattle represents a risk factor for alphaherpesvirus infection. The reason for this can be explained by the greater likelihood that animals purchased without the health marketing criteria may be infected. However, this variable had no significant association with BoHV-1 infection in this study (Table 2).

With regard to grass sharing, ACKERMANN; ENGELS (2006) and DIAS et al. (2008) emphasize that the use of pastures in common with other properties contributes to the contact between susceptible and infected animals, favoring the spread of the virus through ocular and nasal secretions, inhalation of aerosols and by direct contact with infected fetal attachments, but in this research there was no statistically significant association between this variable and seropositivity for the alphaherpesvirus (Table 2).

Regarding the history of abortion, FRANDOLOSO et al. (2008) say that BoHV-1 infections can cause infertility, embryonic death, fetal death and abortion, especially between the fifth and eighth month of gestation, and this factor was already associated with DIAS et al. (2008) to positivity of BoHV-1 in creations in the state of Paraná. However, in this study, previous history of abortion did not present statistical significance, according to Table 2 . This finding corroborates the results of BARBOSA et al. (2005), SOUSA et al. (2013) and BEZERRA et al. (2012b), who also did not verify the relationship between the history of abortions and the prevalence of BoHV-1 in the cattle herds investigated.

\section{CONCLUSIONS}

The results obtained in this study demonstrated high prevalence of seropositivity for BoHV-1 in dairy farms in the municipality of Senador Guiomard, indicating that the virus is widely distributed in the region. The variable lack of veterinary care showed statistically significant association and was identified as a risk factor for seropositivity to alphaherpesvirus. Thus, it is essential that the infection of the herds is controlled by prophylactic measures and sanitary management by the owners in conjunction with the animal health services through periodic serological tests, vaccination campaigns and gradual substitution of infected animals for healthy ones. In addition, it is also necessary to develop new studies in order to describe and understand the epidemiological profile of alphaherpesvirus infection in Acre cattle.

| | | | | | | | | | | | | | | | | | | | | | | | | | | | | | | | | | | | | | | | | | | | | | | | | | | | | | | | | | | | | | | | | | | | | | | | | | | | | | | | | | | | | | | | | | | | | | | | | | | | | | | | | | | | | | | | | | | | | | | | | | | | | | | | | | | | | | | | | | | | | | | | | | | | | | | | | | | | | | | | | | | | | | | | | | | | | | | | | | | | | | | | | | | | | | | | | | | | | | | | | | | | | | | | | | | | | | | | | | REFERENCES

ACKERMANN, M.; ENGELS, M. Pro and contra IBR eradication. Veterinary Microbiology, v.3 1, n.3-4, p.293-302, 2006. https:// doi.org/10.1016/j.vetmic.2005.11.043

AFFONSO, I.B.; AMORIL, J.G.; ALEXANDRINO, B.; BUZINARO, M.G.; MEDEIROS, A.S.R. Anticorpos contra o herpesvírus bovino tipo 1 (BoHV-1) nas dez regiões de planejamento do Estado de Goiás, Brasil. Ciência Animal Brasileira, v.1 1, n.4, p.892-898, 2010. http://dx.doi.org/10.5216/cab.v1 1 i4.6318

AGUIAR, T.S. Relação de doadoras infectadas pelo herpesvírus bovino tipo 1 e vírus da diarreia viral bovina com a produção in vitro e in vivo de embriões. 2014. 70p. Dissertação (Mestrado em Ciência Animal) - Centro de Ciências Agroveterinárias, Universidade do Estado de Santa Catarina, Lages, 2014.

ALEXANDRINO, B.; DIAS, F.C.; OLIVEIRA, M.C.; AFFONSO, I.B.; PEREIRA, G.T.; SAMARA, S.I. Herpesvírus bovino associado à diarreia viral bovina e à leucose enzoótica bovina. ARS Veterinária, Jaboticabal, v.27, n.3, p.168-174, 2011.

BARBOSA, A.C.V.C.; BRITO, W.M.E.D.; ALFAIA, B.T. Soroprevalência e fatores de risco para a infecção pelo herpesvírus bovino tipo 1 (BHV-1) no Estado de Goiás, Brasil. Ciência Rural, v.35, n.6, p.1368-1373, 2005. http://dx.doi.org/10.1590/SO103-84782005000600022

BEZERRA, D.C.; CHAVES, N.P.; SOUSA, V.E.; SANTOS, H.P.; PEREIRA, H.M. Fatores de risco associados à infecção pelo herpesvírus bovino tipo 1 em rebanhos bovinos leiteiros da região amazônica maranhense. Arquivos do Instituto Biológico, v.79, n.1, p.107-111, 2012a. http://dx.doi.org/10.1590/ S1808-16572012000100016

BEZERRA, D.C.; CHAVES, N.P.; SOUSA, V.E.; SANTOS, H.P.; PEREIRA, H.M. Prevalência e fatores de risco associados à infecção pelo herpesvírus bovino tipo 1 em rebanhos bovinos leiteiros no estado do Maranhão. Revista Brasileira de Ciência Veterinária, v.19, n.3, p.158-162, 2012 b. http://dx.doi. org/10.4322/rbcv.2014.099

CARBONERO, A.; SAA, L.R.; JARA, D.V.; GARCÍA-BOCANEGRA, I.; ARENAS, A.; BORGE, C.; PEREA, A. Seroprevalence and risk factors associated to bovine herpesvírus 1 (BHV-1) infection in non-vaccinated dairy and dual purpose cattle herds in Ecuador. Preventive Veterinary Medicine, v.100, n. 1, p.84-88, 201 1. http:// dx.doi.org/10.1016/j.prevetmed.2011.03.006 
CAVALCANTE, F.A. Rinotraqueíte infecciosa bovina (IBR), no estado do Acre. v.102. Rio Branco: Embrapa-CPAF/AC, 1997. p.1-3.

DEL FAVA, C.; PITUCO, E.M.; D’ANGELINO, J.L. Herpesvírus bovino tipo 1 (HVB-1): revisão e situação atual no Brasil. Revista Educação Continuada, CRMV-SP. v.5, n.3, p.300-12, 2002.

DIAS, J.A.; ALFIERI, A.A.; MEDICI, K.C.; FREITAS, J.C.; FERREIRA NETO, J.S.; MÜLLER, E.E. Fatores de risco associados infecção pelo herpesvírus bovino tipo 1 em rebanhos bovinos da região Oeste do Estado do Paraná. Pesquisa Veterinária Brasileira, v.28, n.3, p.161-168, 2008

DINIZ, J.V.A.; SATRAPA, R.; PITUCO, E.M.; PIVATO, I.; OBA, E. Herpesvírus bovino tipo 1 e sua ação em receptoras no estado do Acre. Revista CFMV, Brasília, ano 21, n.65, p.55-58, 2015.

FRANDOLOSO, R.; ANZILIERO, D.; SPAGNOLO, J.; KUSE, K.; FIORI, C.; SCORTEGAGNA, G.T.; BARCELLOS, L.J.G.; KREUTZ, L.C. Prevalência de leucose enzoótica bovina, diarreia viral bovina, rinotraqueíte infecciosa bovina e neosporose bovina em 26 propriedades leiteiras da região nordeste do Rio Grande do Sul, Brasil. Ciência Animal Brasileira, v.9, n.4, p. 1 102-1 106, 2008.

FREITAS, E.J.P.; LOPES, C.E.R.; MOURA FILHO, J.M.; SÁ, J.S.; SANTOS, H.P.; PEREIRA, H.M. Frequência de anticorpos contra o herpesvírus bovino tipo 1 (BoHV-1) em bovinos de corte não vacinados. Semina: Ciências Agrárias, Londrina, v.35, n.3, p.1301-1310, 2014. http://dx.doi.org/10.5433/1679-0359.2014v35n3p 1301

GUARINO, H.; NÚÑEZ, A.; REPISO, M.V.; GIL, A.; DARGATZ, D.A. Prevalence of serum antibodies to bovine herpesvirus- 1 and bovine viral diarrhea virus in beef cattle in Uruguay. Preventive Veterinary Medicine, v.85, n. 1-2, p.34-40, 2008. http://dx.doi. org/10.1016/j.prevetmed.2007.12.012

HOLZ, C.L.; CIBULSKI, S.P.; TEXEIRA, T.F.; BATISTA, H.B.C.R.; CAMPOS, F.S; SILVA, J.R.; VARELA, A.P.M.; CENCI, A.; FRANCO, A.C.; ROEHE, P.M. Soroprevalência de herpesvírus bovinos tipos 1 e/ou 5 no estado do Rio Grande do Sul. Pesquisa Veterinária Brasileira, v.29, n.9, p.767-773, 2009. http://dx.doi.org/10.1590/S0100-736X2009000900014

INSTITUTO BRASILEIRO DE GEOGRAFIA E ESTATÍSTICA - IBGE. Censo Demográfico 2010. Available from: <https://ww2.ibge. gov.br/home/estatistica/populacao/censo2010/default.shtm>. Access on: Jan. 10, 2019.

MAGAÑA-URBINA, A.; RIVERA, J.L.S.; SEGURA-CORREA, J.C. Rinotraqueitis infecciosa bovina en hatos lecheros de la región Cotzio-Téjaro, Michoacán, México. Técnica Pecuaria en México, v.43, n. 1, p.27-37, 2005.

OKUDA, L.H.; AGUIAR, D.M.; CAVALCANTE, G.T.; STEFANO, E.; DEL FAVA, C.; PITUCO, E.M., LABRUNA, M.B.; CAMARGO, L.M.A.; GENNARI S.M. Inquérito soro-epidemiológico do herpesvírus bovino tipo 1 (BOHV-1) no município de Monte Negro, estado de Rondônia, Brasil. Arquivos do Instituto Biológico, v.68, n.2, p.272-275, 2006.

OLIVEIRA, M.T.; CAMPOS, F.S.; DIAS, M.M.; VELHO, F.A.; FRENEAU G.E.; BRITO, W.M.; RIJSEWIJK, F.A.; FRANCO, A.C.; ROEHE, P.M.
Detection of bovine herpesvirus 1 and 5 in semen from Brazilian bulls. Theriogenology, v.75, n.6, p.1139-1145, 2011. https:// doi.org/10.1016/j.theriogenology.2010.11.025

OLIVEIRA, R.A.M.; LORENZETTI, E.; ALFIERI, A.A.; LISBOA, J.A.N. Prevalência das infecções latentes por BoHV-1 e BoHV-5 em bovinos de corte no Estado do Paraná. Arquivo Brasileiro de Medicina Veterinária e Zootecnia, v.67, n.5, p.1217-1225, 2015. http://dx.doi.org/10.1590/1678-4162-7496

PASQUALOTTO, W.; SEHNEM, S.; WINCK, C.A. Incidência de rinotraqueíte infecciosa bovina (IBR), diarreia viral bovina (BVD) e leptospirose em bovinos leiteiros da região oeste de Santa Catarina - Brasil. Revista em Agronegócio e Meio Ambiente, v.8, n.2, p.249-270, 2015 . http://dx.doi. org/10.17765/2176-9168.2015v8n2p249-270

PIOVESAN, M.; FERNANDES, M.H.V.; CORRÊA, R.A.; PRADO, M.H.J.; CAMARGO, A.D.; RODRIGUES, P.R.C. Anticorpos contra o herpesvírus bovino tipo 1, vírus da diarreia viral bovina e vírus da leucose enzoótica bovina na região da campanha do estado do Rio Grande do Sul. Science and Animal Health, v.1, n.1, p.38-49, 2013. http://dx.doi.org/10.15210/sah. v1i1.2609

SANTOS, M.R.; FERREIRA, H.C.C.; SANTOS, M.A.; SARAIVA, G.L.; TAFURI, N.F.; SANTOS, G.M.; TOBIAS, F.L.; MOREIRA, M.A.S.; ALMEIDA, M.R.; SILVA JÚNIOR, A. Antibodies against bovine herpesvirus 1 in dairy herds in the state of Espírito Santo, Brazil. Revista Ceres, v.61, n.2, p.280-283, 2014. http://dx.doi. org/10.1590/SO034-737X2014000200017.

SILVA, F.S.; OLIVEIRA, J.M.B.; BATISTA FILHO, A.F.B.; RIBEIRO, C.P.; PITUCO, E.M.; PINHEIRO JUNIOR, J.W. Análise soroepidemiológica da infecção pelo herpesvírus bovino tipo 1 (BoHV-1) em bovinos no Estado de Pernambuco. Acta Scientiae Veterinariae, v. 43, n. 1324, p. 1-11, 2015.

SOUSA, V.E.; BEZERRA, D.C.; CHAVES, N.P.; SANTOS H.P.; PEREIRA H.M. Frequência de anticorpos e fatores de risco associados à infecção pelo vírus da diarreia viral bovina (BVDV) e herpesvírus bovino tipo 1 (BoHV-1) em fêmeas bovinas leiteiras criadas em sistema de produção semiintensivo. Revista Brasileira de Medicina Veterinária, v.35, n. 1, p.21-25, 2013.

TAKIUCHI, E.; ALFIERI, A.F.; ALFIERI, A.A. Herpesvírus bovino tipo 1: Tópicos sobre a infecção e métodos de diagnóstico. Semina: Ciências Agrárias, Londrina, v.22, n.2, p.203-209, 2001.

VIU, M.A.O.; DIAS, R.L.O.; LOPES, D.T.; VIU, A.F.M.; FERRAZ, H.T. Rinotraqueíte infecciosa bovina: revisão. PUBVET, v.8, n.4, 2014

WORLD ORGANIZATION FOR ANIMAL HEALTH. Manual of diagnostic tests and vaccines for terrestrial animals. Paris: OIE, 2010. Available from: https://pdfs.semanticscholar.org/d1 29 /90569d56412be4cec406c4f126e3644574b 1.pdf. Access on: Jan. 10, 2019. 